\title{
PENDAMPINGAN PENERAPAN MANAJEMEN PEMBELAJARAN BERBASIS MULTIPLE INTELLIGENCES DI SMA KECAMATAN WAY JEPARA KABUPATEN LAMPUNG TIMUR
}

\begin{tabular}{c|c|c} 
& Jamiluddin Yacub \\
& jamiluddinyacub@yahoo.co.id & \\
& STAI Darussalam Lampung \\
\hline \hline Received: & Revised: & Aproved: \\
14/06/2021 & $22 / 06 / 2021$ & $22 / 06 / 2021$ \\
\hline \hline
\end{tabular}

\begin{abstract}
This study aims to describe, reveal, and find the dominant factors of multiple intelligence-based learning management in improving learning achievement in the field of life skills. The focus of this research is on planning, organizing, implementing, evaluating, and learning outcomes. This study uses a qualitative design with a naturalistic approach and based on constructivism, which views reality as having multiple dimensions, data were collected through interviews, observation, documentation, and triangulation. The results of this study conclude that multiple intelligence-based learning management is very effective for fulfilling students' life skills, that each student can develop their respective types of intelligence in various ways, intelligence is not only limited to IQ, but there are other intelligences including linguistic intelligence, Mathematical logic, spatial, kinesthetic, musical, interpersonal, intrapersonal, and naturalistic. Learning management based on multiple intelligences begins with MIR (multiple intelligences research for each new student as the basis for preparing lesson plans. The learning implementation is preceded by apperception containing alpha zones in the form of special greetings, fun stories, ice breaking, or singing. The core activities consist of exploration, elaboration, and singing). confirmation, apperception exploration in the form of warmer, pre-teach, and scene setting, elaboration containing learning strategies and methods, while confirmation in the form of teacher and student questions and answers to determine lesson acceptance, Evaluation by means of authentic assessment which includes three domains of knowledge (cognitive) consisting of tests daily, UTS, UAS, annual test, attitude (affective) assessment of teachers, self, friends, and anecdotal records, assessment of skills (psychomotor) in the form of performance (performance), work (product), and making projects (project). The obstacle to learning management based on Multiple Intelligences is changing the paradigm a teacher, making lesson plans, choosing varied learning strategies, and conducting authentic student assessments.
\end{abstract}




\title{
Keywords: Mentoring, Implementation, Learning Strategies, Multiple Intelligences
}

\begin{abstract}
Abstrak
Penelitian ini bertujuan untuk mendeskripsikan, mengungkapkan, dan menemukan faktor dominan manajemen pembelajaran berbasis multiple intelligence dalam meningkatkan prestasi belajar bidang life skills, Fokus penelitian ini pada perencanaan, pengorganisasian, pelaksanaan, evaluasi, dan hasil pembelajaran, Penelitian ini menggunakan desain kualitatif dengan pendekatan naturalistik dan didasarkan pada paham konstruktivisme, yang memandang sesuatu kenyataan berdimensi jamak, data dikumpulkan melalui wawancara, observasi, dokumentasi, dan triangulasi. Hasil penelitian ini menyimpulkan bahwa manajemen pembelajaran berbasis multiple intelligence sangat efektif untuk pemenuhan life skills siswa, bahwa setiap siswa dapat mengembangkan jenis kecerdasannya masing-masing dengan beragam cara, kecerdasan bukan hanya terbatas IQ saja, tetapi ada kecerdasan lain diantaranya kecerdasan linguistic, logic Matematic, spasial, kinestetik, musical, interpersonal, intrapersonal, dan naturalistic. Manajemen pembelajaran berbasis multiple intelligences diawali dengan MIR (multiple intelligences research pada setiap siswa baru sebagai dasar penyusunan lessonplan. Pelaksanaan pembelajaran didahului dengan apersepsi berisi alfa zona berupa salam special, fun story, ice breaking, atau bernyanyi. Kegiatan intinya terdiri eksplorasi, elaborasi, dan konfirmasi. eksplorasi apersepsi berupa warmer, pre-teach, dan scene setting, elaborasi berisi strategi dan metode belajar, sedangkan konfirmasi berupa tanya jawab guru dengan siswa untuk mengetahui penerimaan pelajaran, Evaluasi dengan cara penilaian autentik yang mencakup tiga ranah pengetahuan (kognitif) terdiri ulangan harian, UTS, UAS, ulangan tahunan, sikap (afektif) penilaian guru, diri sendiri, teman, dan anecdot record, penilaian keterampilan (psikomotorik) berbentuk unjuk kerja (performance), hasil karya (produc), dan membuat proyek (project). Hambatan manajemen pembelajaran berbasis Multiple Intelligences adalah mengubah paradigma guru, membuat lesson plan, pemilihan strategi belajar bervariasi, dan melakukan penilaian autentik siswa.
\end{abstract}

\section{Kata Kunci: Pendampingan, Penerapan, Strategi Pembelajaran, Multiple Intelligences}

\section{A. Pendahuluan}

Pendidikan adalah suatu upaya untuk mengembangkan potensi kecerdasan

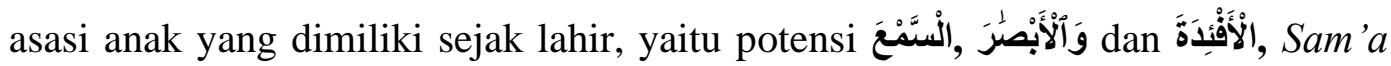
secara fisik berarti pendengaran, makna hakekat berarti kepekaan, secara filsafi 
bermakna kepedulian, Al-Abshor secara fisik berarti penglihatan, secara hakekat berarti pandangan, secara filsafi bermakna wawasan, dan Af'idah secara fisik bermakna pemahaman, secara hakekat bermakna pengamatan, dan secara filsafi bermakna analisa.

Potensi asasi ini merupakan sesuatu hal yang dapat berkembang dan dipergunakan secara maksimal, karena sangat relevan dengan fitrah manusia dan tujuan pendidikan Nasional kita yaitu untuk berkembangnya potensi peserta didik agar menjadi manusia yang beriman dan bertakwa kepada Tuhan Yang Maha Esa, berakhlaq mulia, sehat, berilmu, cakap, kreatif, mandiri, dan menjadi warga negara yang demokratis serta bertanggung jawab, sedangkan fungsi pendidikan adalah untuk mengembangkan kemampuan dan membentuk watak serta peradaban bangsa yang bermartabat dalam rangka mencerdaskan kehidupan bangsa.

Tujuan dan fungsi pendidikan diatas adalah merupakan cita-cita besar yang harus dicapai dengan menggunakan berbagai metode dan strategi salah satunya adalah dengan menggunakan strategi pembelajaran berbasis multiple intelligence, yang memahami bahwa setiap anak memiliki jenis kecerdasan yang berbeda-beda yang harus dikembangkan sesuai dengan janis kecerdasan itu sendiri, dan jenis kecerdasan itu dapat dijadikan pintu masuknya ilmu pengetahuan baru.

Pembelajaran yang tidak memperhatikan pada jenis kecerdasan anak akan merugikan anak itu sendiri, maka sangat disayangkan jika anak yang memiliki gifted tertentu tidak dikembangkan pada jenis kecerdasannya masing-masing karena selama ini sekolah atau lembaga pendidikan kita hanya memperhatikan kecerdasan siswa dari segi IQ saja, dibuktikan dengan adanya pembelajaran di kelas yang masih memaksakan anak untuk mengembangkan kecerdasan logika matematika dan bahasa saja tanpa mengetahui, mengembangkan, dan bahkan mengacuhkan jenis kecerdasan lain yang merupakan kecerdasan unik siswa padahal ini sebagai kunci kesuksesan anak dimasa yang akan datang.

Hal ini terjadi karena di sekolah atau lembaga pendidikan terutama di SMA memiliki tenaga didik yang menguasai strategi pembelajaran sangat terbatas sehingga penerapan multistrategi di kelas kurang menyentuh sisi kecerdasan majemuk atau multiple intelligence anak. 


\section{Pembelajaran Yang Ideal}

Idealnya pembelajaran yang baik dilaksanakan oleh guru dan sekolah mengacu pada empat prinsip pembelajaran yaitu Students Talking Time, pembelajaran yang difokuskan pada anak, guru menjelaskan materi ajar dengan porsi antara 30-40\%, dan murid mendapatkan porsi terbesar yaitu antara $60-70 \%$ untuk beraktivitas sesuai dengan materi yang dipelajari, Global Analysis, mata pelajaran atau pokok bahasan yang dipelajari murid harus mampu memberikan gambaran secara utuh dari sebuah mata pelajaran, materi pelajaran, dan bahkan kegunaan dan manfaat mata pelajaran dan pokok bahasan yang dipelajarinya, sehingga murid mempunyai pengertian secara global apa kegunaan dan manfaat mata pelajaran, bab, pokok bahasan, sub pokok bahasan yang sedang dipelajari.

Interactif book, adalah anak belajar dan berinteraksi dengan buku pelajaran, bukan buku yang hanya bisa dibaca saja, namun buku yang bisa dicoret, bisa digambari, bisa digunting, bisa tempel, bisa dilipat, bisa diwarnai, dan bisa dihias dan dijadikan tempat menggambar dan menempel, mengajak siswa berdiskusi, mencari sumber belajar lain, dibuat role play, membuat drama, mencipta sesuatu, dan melibatkan orang ketiga seperti orangtua, teman dan orang lain dalam mempelajari buku pelajaran itu.

Heterogen Class adalah pembagian kelas atau kelompok heterogin yang diawali sejak penerimaan murid baru, pembagian kelas, pembagian kelompok dan lain sebagainya, prinsip heterogen class adalah kelas yang muridnya dibagi bukan menurut tingkat kecerdasan namun dibagi menurut jenis kecerdasan atau nomor urut.

\section{Realita Pembelajaran di SMA}

Lembaga pendidikan kita terutama di SMA masih banyak guru justru melakukan hal sebaliknya yaitu Teacher Talking Time, Task Analysis, Textbook, dan Tracking class, menurut Armstrong guru yang melakukan empat hal ini disebut melakukan Disteachia yaitu mallpraktik pendidikan.

Teacher Talking Time, guru menghabiskan $80 \%$ bahkan ada yang sampai 100\% waktunya di kelas untuk berceramah, berbicara sendiri tanpa memperhatikan murid, guru mengajar namun murid belum tentu belajar, guru berceramah 
menganggap muridnya mendengarkan ceramahnya padahal kenyataannya murid kebanyakan tidak memperhatikan, ngobrol, melamun, bahkan ada yang tidur, guru yang terkena virus ini menganggap dirinya sudah cukup untuk memenuhi kewajiban mengajar.

Task Analysis, Guru biasanya langsung masuk pada materi pelajaran tanpa menjelaskan kegunaan materi atau bab atau sub-bab yang akan dipejari dengan kehidupan sehari-hari, materi ajar berupa potongan-potongan yang seharusnya murid mendapat gambaran seperti apa materi yang akan dipelajari, setelah materi disampaikan murid tidak akan bingung karena sudah mempunyai gambaran kegunaan dari materi yang dipelajari itu.

Textbook, setiap guru mengajar selalu meminta murid membuka bukunya, mengerjakan soal-soal, padahal interaksi buku dan murid hanya satu arah saja, virus Tracking class yaitu pendidikan yang mengelompokkan siswa ke dalam kelas atau kelas berdasarkan kemampuan kognitifnya, salah satu outputnya adalah cara pembagian kelas berdasarkan kelas untuk anak pintar dan kelas untuk anak bodoh dan sebagainya.

Fakta pembelajaran di SMA kecamatan Way Jepara kabupaten Lampung Timur yang diperoleh melalui penyebaranan angket kepada guru dan wawancara kepada Kepala SMA maka dapat dirumuskan bahwa permasalahannya adalah "Masih kurangnya guru yang menerapkan multi strategi pembelajaran di SMA di Kabupaten Lampung Timur tahun pelajaran 2018-2019”.

Berdasarkan permasalahan diatas maka dapat dimasukkan dalam tabel sebagaimana dibawah ini:

TABEL 1

PERMASALAHAN

PENERAPAN MULTI STRATEGI BELAJAR DI SMA LAMPUNG

\begin{tabular}{|c|c|c|c|c|}
\hline \multirow[b]{2}{*}{$\mathrm{NO}$} & \multirow[b]{2}{*}{ LINGKUP } & \multirow[b]{2}{*}{ SEHARUSNYA } & \multicolumn{2}{|c|}{ KENYATAANYA } \\
\hline & & & $\begin{array}{c}\text { Kondisi Yang } \\
\text { Terjadi }\end{array}$ & $\begin{array}{c}\text { Kondisi Yang } \\
\text { Terjadi Sekarang }\end{array}$ \\
\hline 1 & $\begin{array}{l}\text { Strategi } \\
\text { Pembelajaran }\end{array}$ & $\begin{array}{l}\text { Guru mengajar } \\
\text { menggunakan } \\
\text { multi strategi }\end{array}$ & $\begin{array}{l}\text { Guru mengajar } \\
\text { kurang } \\
\text { menerapkan atau } \\
\text { menggunakan }\end{array}$ & $\begin{array}{l}\text { 1. Prosedur } \\
\text { pembelajaran } \\
\text { kurang sistematis }\end{array}$ \\
\hline
\end{tabular}




\begin{tabular}{|l|l|l|l|}
\hline & & multi strategi & 2. Pembelajaran \\
pembelajaran & kurang efektif \\
& & 3. Sebagian besar \\
& & murid kurang \\
& & mengikuti \\
& & penjelasan guru \\
& & 4. Anak didik kurang \\
& & fokus \\
\hline
\end{tabular}

\section{Pendampingan Penerapan Strategi Belajar di SMA}

Berdasarkan hasil angket pada tanggal 22 Agustus 2018 terhadap guru SMA kabupaten Lampung Timur menunjukkan bahwa guru yang menerapkan multi strategi mengajar masih sangat bervariasi sebagaimana tertera pada tabel berikut:

TABEL 2

HASIL ANGKET

\begin{tabular}{|l|c|c|c|c|}
\hline NO & $\begin{array}{c}\text { NAMA } \\
\text { SEKOLAH }\end{array}$ & JUMLAH GURU & $\begin{array}{c}\text { MULT } \\
\text { STRATEG } \\
\text { I }\end{array}$ & $\begin{array}{c}\text { PROSEN } \\
\text { TASE }\end{array}$ \\
\hline 1 & $\mathrm{~A}$ & 20 & 5 & $25 \%$ \\
\hline 2 & $\mathrm{~B}$ & 15 & 5 & $33 \%$ \\
\hline 3 & $\mathrm{C}$ & 10 & 5 & $50 \%$ \\
\hline 4 & $\mathrm{D}$ & 20 & 5 & $25 \%$ \\
\hline 5 & $\mathrm{E}$ & 10 & 2 & $20 \%$ \\
\hline 6 & $\mathrm{~F}$ & 10 & 3 & $30 \%$ \\
\hline 7 & $\mathrm{G}$ & 10 & 3 & $30 \%$ \\
\hline \multicolumn{2}{|r}{ Rata-rata Sumber: Angket tanggal 22 Agustus 2018 } & $30 \%$ \\
\hline
\end{tabular}

Merujuk pada tabel diatas menunjukkan bahwa penerapan multi strategi belajar yang diterapkan oleh guru SMA di Way Jepara Kabupaten Lampung Timur Tahun Ajaran 2018/2019 baru mencapai 30\%, data ini berdasarkan hasil wawancara dengan beberapa Kepala SMA dan guru bahwa faktanya masih banyak guru SMA di Kecamatan Way Jepara Kabupaten Lampung Timur belum sepenuhnya menggunakan multi strategi dalam proses pembelajaran di kelas, masih banyak guru yang mengajar hanya menggunakan metode ceramah saja, bahkan berdasarkan wawancara dengan guru SMA masih kesulitan untuk menerapkan multi strategi belajar dengan materi pelajaran dan ditambah dengan terlalu 
banyaknya anak dalam satu rombongan belajar, sebagian guru lain masih kesulitan membagi porsi waktu lebih banyak diberikan kepada anak didik tanpa harus meninggalkan kelas.

\section{B. Pembahasan}

\section{Strategi Pelaksanaan Pendampingan}

Pendampingan penerapan strategi belajar berbasis multiple intelligences di SMA kecamatan Way Jepara Kabupaten Lampung Timur menggunakan beberapa strategi dan tahapan yaitu Strategi Pelatihan, Strategi pendampingan sekolah, Strategi pendampingan Kelas, dengan tahapan sebagai berikut:

1. Pelatihan, tahap pelatihan ini dilaksanakan secara berkala pada hari minggu dimulai pada tanggal 23 September 2018, pelaksanaan pertama diselenggarakan di STAI Darussalam Lampung yang diikuti peserta berjumlah 32 orang guru dari 7 SMA di kecamatan Way Jepara kabupaten Lampung Timur dengan materi open maind multi strategi sebelum masuk pada materi strategi belajar berbasis Multiple Intelligences materinya adalah sebagai berikut:
a. Distechia dalam Pendidikan
b. Gaya Belajar Siswa
c. Semua Anak Cerdas
d. Teori Strategi Belajar Multiple Intelligences

2. Pendampingan ke Sekolah dan Kelas, pada tahap pelaksanaan pendampingan dimulai pelatihan bertempat di STAI Darussalam Lampung dan dilanjutkan di SMA materi penerapan strategi belajar berbasis Multiple Intelligences bagi Guru SMA, setelah beberapa kali pertemuan untuk pendalaman dilanjutkan pendampingan kepada guru ke kelas masing-masing.

\section{Metode dan Strategi Pendampingan}

Metode yang digunakan dalam pendampingan ini adalah metode Participation Action Research yaitu metode penelitian dan pengembangan yang dilaksanakan secara partisipatif oleh komunitas yang memiliki kesamaan tujuan, hubungan sosial, pengalaman, pikiran, dan perasaan yang bertujuan untuk mencari 
suatu hubungan proses penelitian ke dalam proses perubahan sosial, Participation Action Research sering disebut PAR, PAR memiliki beberapa nama diantara adalah action research, collaborative inquiry, dan collaborative action.

Metode PAR berbeda dengan metode penelitian ilmiyah lainya yang biasa dilakukan oleh para akademisi, lembaga survey, dan lain sebagainya, pada metode penelitian ilmiah umumnya seorang Peneliti menjadikan suatu kelompok masyarakat hanya sebagai objek yang diteliti untuk mendapatkan suatu inti permasalahan tanpa memberikan perubahan atau transformasi nilai apapun dalam suatu masyarakat tersebut, sedangkan dalam metode PAR seorang Peneliti bertindak sebagai fasilitator terjadinya proses penelitian yang partisipatif di antara anggota komunitas tersebut sehingga terjadi perubahan yang sama bagi komunitas itu sendiri, PAR menuntut adanya pendefinisian bersama dan pelaksanaan penelitian dalam bentuk aksi sebagai solusi atas masalah yang telah terdefinisi.

Metode PAR (Participation, Action, dan Research) memiliki lima prinsip yang harus dilaksanakan secara bersamaan dan tidak dapat ditinggalkan, prinsip tersebut adalah:

1. Participation, Prinsip partisipasi yaitu PAR harus dilaksanakan dengan melibatkan sebanyak mungkin anggota komunitas yang berkepentingan dengan perubahan situasi yang lebih baik, harus dilakukan bersama di antara anggota komunitas melalui proses berbagi dan belajar bersama, untuk memperjelas kondisi dan permasalahan mereka sendiri. Prinsip ini juga menuntut penghargaan pada setiap perbedaan yang melatarbelakangi anggota komunitas saat terlibat dalam Participation Action Research.

2. Action, Prinsip action ini menuntut seluruh kegiatan dalam penelitian PAR (Participation action Research) harus mengarahkan anggota komunitas untuk melakukan aksi-aksi transformatif mengubah kondisi sosial mereka agar menjadi semakin baik, oleh karena itu PAR (Participation action Research) harus memuat agenda aksi yang jelas, terjadwal, dan konkret.

3. Research, Prinsip research adalah sebuah proses yang menghasilkan pengetahuan yang mencakup empat domain pengetahuan yaitu experiental, presentational, propositional, practical (John Heron 1996), dan diarahkan 
oleh partisipan untuk pelaksanaan terbaik bagi kepentingan masyarakat, pengetahuan dikembangkan melalui dialog reflektif dan analisis kritis yang dilakukan oleh partisipan yang terlibat dalam aksi tersebut,

4. Triangulasi, Prinsip triangulasi dalam PAR (Participation Action Research) harus dilakukan dengan memperhatikan dari berbagai sudut pandang, metode, alat kerja yang berbeda untuk memahami situasi yang sama, agar pemahaman tim peneliti bersama anggota komunitas terhadap situasi tersebut semakin lengkap dan sesuai dengan fakta, setiap informasi yang diperoleh harus diperiksa ulang lintas kelompok warga atau elemen komunitas (crosscheck), prinsip ini menuntut PAR (Participation action Research) mengandalkan data-data primer yang dikumpulkan sendiri oleh peneliti bersama anggota komunitas di lapangan, sedangkan data sekunder (penelitian lain, kepustakaan, statistik formal) dimanfaatkan sebagai pembanding.

5. Fleksible, Prinsip fleksibel dalam PAR (Participation Action Research) dilakukan dengan perencanaan sangat matang, pelaksanaan yang cermat, dan hati-hati, peneliti bersama anggota komunitas harus tetap bersikap fleksibel dalam menghadapi perubahan situasi yang mendadak, agar mampu menyesuaikan rencana semula dengan perubahan tersebut, dalam prinsip fleksibel ini bukan situasinya yang dipaksa sesuai dengan desain riset, melainkan desain riset yang menyesuaikan diri dengan perubahan situasi.

PAR (Participation Action Research) memiliki kegiatan bahwa peneliti tidak memisahkan diri dari situasi masyarakat yang diteliti, melainkan melebur ke dalamnya dan bekerja bersama warga dalam melakukan Action Research secara Participation, yang membahas kondisi masyarakat berdasarkan sistem makna yang berlaku di tempat itu, bukan menurut disiplin ilmu tertentu di luar budaya masyarakat tersebut.

Participation Action Research tidak bisa berposisi "bebas nilai" seperti penelitian ilmiyah lain dan tidak memihak seperti yang dituntut ilmu pengetahuan sebagai syarat obyektivitas, melainkan harus memihak pada kelompok yang lemah, miskin, dirugikan, dan menjadi korban, selain itu Participation Action Research tidak berhenti pada publikasi hasil penelitian (laporan) dan rekomendasi untuk 
penelitian berikutnya, melainkan berorientasi pada perubahan situasi, peningkatan kuantitas pengetahuan dan kualitas kemampuan masyarakat dan warga untuk memahami dan mengubah situasi mereka menjadi lebih baik.

Participation Action Research (PAR) memiliki kelebihan yang tidak dimiliki oleh penelitian ilmiyah lainya diantaranya adalah:

1. Masyarakat sebagai subjek penelitian adalah orang tertindas dalam posisinya sebagai pencipta pengetahuan dalam proses transformasi diri mereka sendiri, PAR sebenarnya tidak hanya penelitian yang mengharapkan ada aksi sebagai tindak lanjut dari penelitian, tetapi kemudian ada penelitian kembali dari seluruh peserta, dan ada aksi kembali.

2. Partisipasi yang autentik dapat meningkatkan dan memperbaiki taraf kehidupan sosial masyarakat sebagai subjek yang diteiti, dan membentuk siklus yang berkesinambungan serta kerjasama untuk melakukan perubahan kearah yang lebih baik, penyadaran terhadap komunitas akan situasi yang sedang mereka alami.

3. Membangun pemahaman kondisi sosial secara kritis, melibatkan sebanyak mungkin orang dalam teoritisasi kehidupan sosial, menempatkan pengalaman, gagasan, pandangan dan asumsi sosial, membuat rekaman proses secara cermat.

4. Berusaha memberi pengalaman masyarakat sebagai subjek penelitian, salah satu proses politik dalam arti yang luas, Mensyaratkan adanya analisa relasi sosial secara kritis, Memulai dari isu yang kecil dengan mengaitkan relasi yang lebih luas, Memulai dengan siklus proses yang kecil, Memulai dengan kelompok sosial yang kecil, Mengajak semua pihak untuk mencermati dan membuat rekaman proses, Semua harus dapat memberikan alasan yang rasional atas yang mereka lakukan.

Tujuan PAR (Participation Action Research) adalah agar peneliti menggerakkan proses dengan berbagi pengetahuan dan keterampilan komunitas tersebut, dalam menggerakkan komunitas strategi utama yang harus dimiliki adalah komunikasi yaitu sebuah metodologi kunci dalam PAR (Participation Action Research). Ia menggambarkan kombinasi komunikasi secara kreatif seperti tulisan, 
lisan, dan visual dalam konsep, implementasi, dan dokumentasi penelitian.

Pengembangan pengetahuan secara kritis mengundang pencampuran kreatif dari metode tradisional melalui pertanyaan dan pendekatan, pengunaan metode komunikasi alternatif dalam Participation Action Research mendorong peneliti untuk menguji kembali metode konvensional dan membuka kemungkinan menggunakan metoda yang selama ini tidak pernah mendapatkan legitimasi secara ilmiah.

PAR (Participation Action Research) selalu menitik beratkan pada proses, sehingganya penelitian ini tidak ada kesimpulan akhir, karena menyadari bahwa kondisi objektif masyarakat akan selalu berkembang, berubah dan berdinamika dengan seluruh keterkaitan perubahan-perubahan kondisi objektif yang ada, PAR (Participation action Research) tidak diorientasikan untuk melakukan kesimpulan atas hipotesa kita tentang masyarakat, melainkan menjadi "alat dan senjata analisis" untuk mendorong berbagai perubahan sosial.

Sikap dasar penelitian ini selalu meletakkan dan menitikberatkan pada "kualitas proses" daripada "hasil" sehingga mendorong kecenderungan analisis sosial tidak harus didesain secara baku sebelumnya. Kesahihan sebuah analisis dan riset sosial tidak ditentukan oleh sejauh mana prosedur penelitian itu objektif atau tidak melainkan ditentukan oleh sejauh mana proses, Research aksi partisipatoris tidaklah dilakukan dalam ruang laboratorium melainkan dalam latar alamiah bersama masyarakat, kualaitas research dan analisis berjalan tanpa melalui rekayasa buatan yang sudah didesain sebelumnya.

PAR (Participation action Research) sangat menolak peran intelektual yang berdiri sebagai "arsitektur sosial" yang berjarak dengan komunitas, research bukan hanya sekedar ditempatkan sebagai alat untuk memahami ketidakberdayaan dalam komunitas melainkan berupaya membantu anggota komunitas menuju keberdayaan, research ini sekaligus mempunyai keterikatan moral untuk menjadi "kritik" terhadap suatu pelaksanaan proses tertentu, research ini sangat menghindari sikap dan praktik yang memisahkan penelitian dalam keterkaitan subjek dan objek penelitian, peneliti dan partisipan adalah aktor bersama dalam proses investigasi, saling mempengaruhi, menginterpretasikan berbagai kejadian 
praktik masyarakat, berbagi pengalaman atas pilihan aksi.

Rumusan masalah selalu dilahirkan oleh subjek peneliti bersama komunitas, pendekatan kritis selalu menekankan peran penting dialog menyeluruh di antara subjek peneliti dan masyarakat yang diteliti, hubungan yang terbangun tidaklah dalam peran deterministik "subjek-objek" melainkan "subjek-subjek", PAR (Participation Action Research) banyak diorientasikan untuk "membongkar budaya bisu" komunitas yang sudah sekian lama terbelenggu oleh budaya yang mendominasi, research aksi ini sekaligus berperan penting untuk membongkar pengetahuan yang melegitimasi praktik pembangunan yang berjalan timpang sambil melakukan proses transformasi sosial, hasil yang diharapkan adalah adanya tindakan kritis untuk mendorong perubahan sosial dan memperkuat komunitas yang larut dalam ketimpangan.

PAR (Participation Action Research) sejak awal harus mampu mempersiapkan tujuan akhir dari sebuah penelitian kritis yaitu pemberdayaan yang berorientasi pada aksi perubahan, tugas PAR (Participation Action Research) adalah menentang cara berpikir yang membelenggu dalam ketertindasan dan mampu bertindak secara manusiawi baik secara individu maupun kekompok karena kepentingan dasar research ini adalah "keperpihakan" pada kondisi komunitas yang lemah, adapun teknik yang digunakan dalam pendampingan ini adalah pelatihan, pendampingan, dan penerapan strategi belajar berbasis multiple intelligences di SMA dan pendampingan di kelas.

\section{Pembahasan Strategi Belajar Multiple Intelligences}

Strategi pembelajaran yang tepat dapat diibaratkan sebagaimana strategi memasukkan air ke dalam botol, yang harus dilakukan pertama adalah bagaimana membuka tutup botol-botol itu, kemudian mengisinya dengan air, sedikitnya ada tiga cara untuk membuka tutup botol-botol itu yaitu dengan cara memutar, menusuk, dan mencongkel.

Botol yang menggunakan drat cara membukanya dengan diputar tutupnya, botol yang menggunakan tutup plastik pipih dan tipis cara membuakanya dengan menusuk, sedangkan botol yang menggunakan tutup pres dan keras cara membukanya dengan mencongkel, jika kita tidak mengetahui cara membuka tutup 
botol-botol itu maka dipastikan air yang dimasukkan kedalam botol akan tumpah kemana-mana.

Memperhatikan analogi diatas maka proses pembelajaran sangat ditentukan oleh strategi pembelajaran, guru yang mengajar dengan mengabaikan strategi pembelajaran dapat dipastikan pembelajaran tidak akan efektif, selain strategi pembelajaran gaya mengajar guru juga harus menyesuaikan dengan gaya belajar siswa, sebab jika gaya guru mengajar dengan cara memaksa siswa belajar, sangat dimungkinkan materi pelajaran susah diterima siswa, namun jika strategi pembelajaran berbasis multiple intelligence akan melahirkan pembelajaran yang creatif, efektif, rekreatif, interaktif, dan aktif (CERIA).

Menurut Bobbi DePorter (2002), gaya belajar ada tiga, gaya belajar visual (Visual Learners) adalah belajar yang menitikberatkan pada ketajaman penglihatan, artinya pembelajaran harus ada bukti konkrit yang dapat diperlihatkan terlebih dahulu agar murid dapat memahami materi yang diajarkan, gaya belajar ini murid mengandalkan penglihatan, artinya murid harus melihat dulu buktinya baru kemudian bisa mempercayainya. Karakteristik gaya belajar anak visual untuk memahami informasi atau pelajaran harus melihat sesuatu secara visual, ciri murid visual memiliki kepekaan yang kuat terhadap warna, Memiliki pemahaman yang cukup terhadap masalah artistic, namun memiliki kesulitan dalam berdialog secara langsung, terlalu reaktif terhadap suara, sulit mengikuti anjuran secara lisan, Seringkali salah menginterpretasikan kata atau ucapan.

Kecenderungan gaya belajar visual diantaranya adalah Melihat sikap, gerakan, dan bibir guru yang sedang mengajar., Bukan pendengar yang baik saat berkomunikasi, Saat mendapat petunjuk untuk melakukan sesuatu biasanya akan melihat teman-teman lainnya baru kemudian dia sendiri yang bertindak, Tidak suka bicara didepan kelompok, Tidak suka mendengarkan orang lain, Pasif dalam kegiatan diskusi, Kurang mampu mengingat informasi yang diberikan secara lisan, Lebih suka peragaan daripada penjelasan lisan, duduk tenang di tengah situasi yang ribut dan ramai tanpa terganggu.

Gaya belajar Auditori (Auditory Learners) adalah gaya belajar yang mengandalkan pada pendengaran untuk dapat memahami dan mengingatnya, 
karakteristik gaya belajar auditori ini benar-benar menempatkan pendengaran sebagai alat utama menyerap informasi atau pengetahuan, artinya anak harus mendengar baru bisa mengingat dan memahami informasi itu, karakter gaya belajar auditori diantaranya murid menyerap informasi atau materi pelajaran hanya melalui pendengaran., namun murid memiliki gaya ini memiliki kesulitan untuk menyerap informasi dalam bentuk tulisan secara langsung, anak memiliki kesulitan menulis ataupun membaca.

Anak didik yang memiliki gaya belajar auditori mempunyai ciri-ciri diantaranya adalah mampu mengingat dengan baik penjelasan guru di depan kelas atau materi yang didiskusikan dalam kelompok atau kelas, Pendengar ulung, anak mudah menguasai materi iklan atau lagu di televisi atau radio, Anak cenderung banyak bicara, Anak tidak suka membaca dan umumnya memang bukan pembaca yang baik karena kurang dapat mengingat dengan baik apa yang baru saja dibacanya., Anak kurang cakap dalam mengerjakan tugas mengarang atau menulis., Senang berdiskusi dan berkomunikasi dengan orang lain., Anak kurang tertarik memperhatikan hal-hal baru dilingkungan sekitarnya.

Gaya belajar kinestetik (Kinesthetic Learners) adalah gaya belajar yang menggunakan gerak tubuh yaitu cara anak belajar harus menyentuh sesuatu yang memberikan informasi atau materi pelajaran tertentu agar bisa mengingatnya.

Karakteristik gaya belajar kinestetik diantarnya adalah menempatkan tangan sebagai alat penerima informasi utama agar bisa terus mengingatnya, Memegang adalah sebagai alat utama menyerap informasi tanpa harus membaca penjelasannya, Menyentuh segala sesuatu yang dijumpainya, termasuk saat belajar, Sulit berdiam diri atau duduk manis, Selalu ingin bergerak mengerjakan segala sesuatu yang memungkinkan tangannya aktif, Suka menggunakan objek nyata sebagai alat bantu belajar., Sulit menguasai hal-hal abstrak seperti peta, symbol, dan lambing., Menyukai praktek atau percobaan., Menyukai permainan dan aktivitas fisik.

Gaya guru mengajar yang menyesuaikan dengan gaya murid belajar dan memilih strategi belajar yang tepat dengan gaya belajar murid maka pembelajaran akan berjalan efektif dan menghasilkan murid belajar dalam kondisi Enjoy, menikmati pekerjaanya, Easy mudah melakukannya, Excellent menghasilkan 
sesuatu yang bagus dan unggul, dan Earn, akan mendapatkan hasil yang produktif, yang sering disebut dengan 4E.

Pembelajaran ini adalah pembelajaran yang memperhatikan ranah kognitif, afektif, dan psikomotorik, yaitu pembelajaran secara nyata yang melahirkan anak cerdas, sebagaimana diungkapkan Howard Gardner (1943) bahwa pada hakekatnya setiap anak yang dilahirkan adalah cerdas, bahkan kecerdasan tidak terpatri pada tingkat tertentu dan terbatas saat seseorang lahir, "Setiap orang dapat mengembangkan kecerdasannya dengan beragam cara yang dikenal dengan "multiple intelligence".

Al-Qur'an menjelaskan إن سعيكم لشنىى"Sesungguhnya usaha kamu memang berbeda-beda". Al-Lail (92:4), Semua orang diciptakan dalam keadaan yang sama, tetapi mereka memiliki keunikan masing-masing, maksudnya Allah memberikan kepada manusia kecerdasan namun jenisnya yang berbeda.

Hal ini dapat dijadikan acuan setiap guru dan lembaga pendidikan dalam mendidik dan mengembangkan strategi belajar, guru dan sekolah biasanya hanya memandang siswa dari faktor IQ saja, namun tidak memandang dari jenis kecerdasan lain yang tidak kalah pentingnya dalam mengantarkan anak pada kesuksesan hidupnya.

Hakekatnya semua anak cerdas, sedangkan yang berbeda adalah jenis kecerdasannya, menurut Howard Gardner (1943) setidaknya jenis kecerdasan ada delapan jenis yaitu:

1. Kecerdasan linguistic, cerdas bidang bahasa, mengelola kata dan bahasa.

2. Kecerdasan logika-matematik, kecerdasan bidang angka dan alasan logis.

3. Kecerdasan music, kecerdasan dalam bidang seni musik.

4. Kecerdasan kinestetik, kecerdasan dalam mengolah anggota tubuh.

5. Kecerdasan spasial, kecerdasan dalam permainan garis, warna, dan ruang.

6. Kecerdasan intrapersonal, kecerdasan bidang pengenalan pada diri sendiri.

7. Kecerdasan interpersonal, cerdas membina hubungan dengan orang lain.

8. Kecerdasan naturalistic, kecerdasan behubungan dengan alam.

Amstrong (2002) mengatakan kecerdasan adalah modal untuk melejitkan kemampuan setiap siswa dan menjadikan mereka sebagai sang juara, karena pada 
dasarnya setiap anak adalah "bintang", sementara Munif Chatib (2012) konsep multiple intelligence ada 3 yaitu: (1) Kecerdasan tidak dibatasi dengan tes formal. (2) Kecerdasan itu Multidemensi, dan (3) Kecerdasan ditemukan dengan discovering ability, Al-Qur'an Surat (2:143) menjelaskan "Demikian telah Kami jadikan kalian "Umat Pertengahan" agar kamu menjadi saksi atas perbuatan manusia dan agar Rasulullah menjadi saksi atas perbuatan kamu (Al-Baqarah:143).

Guru dalam memilih strategi pembelajaran diharuskan memperhatikan lima prinsip pembelajaran yaitu Creatif, Efektif, Rekreatif, Interaktif, dan Aktif(CERIA), diantara strategi pembelajaran yang disesuaikan dengan lima prinsip diatas dan dapat menyesuaikan dengan gaya belajar siswa diantaranya adalah Applied Learning, Environment Learning, Service Learning, dan Movie Learning.

Menurut Thomas Amstrong dalam Andi Budimanjaya nahwa strategi pembelajaran multiple intelligences adalah suatu cara mengakses informasi melalui jalur kecerdsan yang ada pada masing-masing siswa namun untuk mengeluarkannya kembali seluruh kecerdasan bersinergi dalam satu kesatuan yang unik sesuai dengan kebutuhan, sehingga siswa mampu memecahkan masalahmasalah pembelajaran dengan cara yang menakjubkan.

Strategi pembelajaran multiple intelligences adalah membuat rasa senang anak didik perhadap proses pembelajaran, pembelajaran fokus pada anak didik, dan membuat anak didik sangat aktif oleh sebab itu pembelajaran multi strategi ini sangat tepat untuk pembelajaran anak didik berusia Sekolah Dasar sehingga siswa berkemampuan rendah dapat menjadi pandai karena dua hal yaitu guru yang tepat dan strategi pembelajaran yang sesuai.

\section{Pelaksanaan Pendampingan Strategi Belajar Multiple Intelligences}

Pelaksanaan pendampingan penerapan strategi belajar berbasis Multiple Intelligences bagi guru SMA di Kecamatan Way Jepara Kabupaten Lampung Timur ini melalui beberapa tahapan sebagai berikut: 


\section{PENDAMPINGAN 1}

\section{STAI DARUSSALAM}

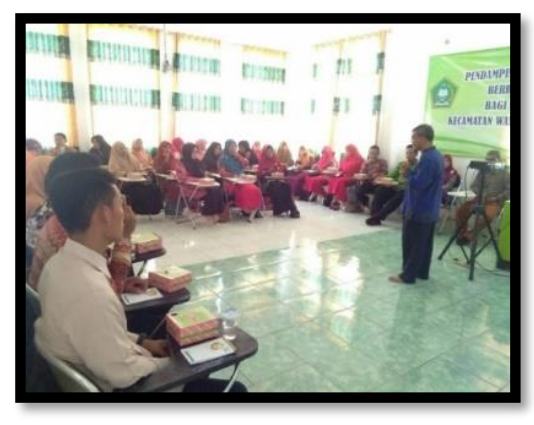

\section{PENDAMPINGAN 2}

\section{SMA MUH 2}

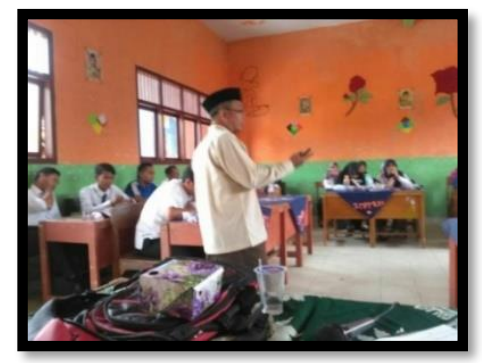

\section{Prosedur Penerapan Strategi Belajar Berbasis Multiple Intelligences}

Prosedur pelaksanaan pendampingan penerapan strategi belajar berbasis Multiple Intelligences bagi guru SMA di Kecamatan Way Jepara Kabupaten adalah sebagai berikut:

\begin{tabular}{|c|c|}
\hline \multicolumn{2}{|l|}{ A. APPLIED LEARNING } \\
\hline 1. Pengertian & $\begin{array}{l}\text { Strategi belajar yang mengaitkan antara konsep } \\
\text { pelajaran dengan manfaat untuk kebutuhan sehari- } \\
\text { hari. }\end{array}$ \\
\hline 2. Prosedur Penerapan & $\begin{array}{l}\text { 1. Konsep, adalah materi yang akan diajarkan kepada } \\
\text { anak didik, biasanya terdapat indikator hasil } \\
\text { belajar. } \\
\text { 2. Aplikasi Nyata, konsep tersebut sebisa mungkin } \\
\text { dibawa kedunia nyata sehingga dapat diaplikasikan } \\
\text { sebagai pemenuhan kebutuhan sehari-hari. }\end{array}$ \\
\hline $\begin{array}{l}\text { 3. Multiple Intelligences } \\
\text { Approach }\end{array}$ & Pendekatan Naturalis dan Kinestetik \\
\hline 4. Contoh Materi & $\begin{array}{l}\text { Memiliki perilaku jujur, disiplin, tanggung jawab, } \\
\text { santun, peduli, dan percaya diri dalam berinteraksi } \\
\text { dengan keluarga, teman, dan guru. }\end{array}$ \\
\hline
\end{tabular}




\begin{tabular}{|c|c|c|}
\hline & \multicolumn{2}{|c|}{$\begin{array}{l}\text { Memiliki perilaku bersih badan, pakaian, barang- } \\
\text { barang, dan tempat sebagai implementasi pemahaman } \\
\text { makna bersuci. }\end{array}$} \\
\hline 5. Contoh Aplikasi Nyata & \multicolumn{2}{|c|}{$\begin{array}{l}\text { 1. Masjid, anak didik diajak menyapu dan ngepel } \\
\text { masjid, menuci sajadah dan telekung masjid, } \\
\text { membersihkan tempat wudul dan toilet masjid } \\
\text { 2. Balai Desa, anak didik diajak bergotong-royong di } \\
\text { Balai Desa, tempat umum lainya untuk melakukan } \\
\text { kebersihan dan merapikan yang belum rapi } \\
\text { 3. Lapangan, dan tempat lain yang bermanfaat bagi } \\
\text { umum yang dapat dijadikan implementasi } \\
\text { pemahaman makna kebersihan yang dapat } \\
\text { dilakukan sebagai pemenuhan kebutuhan sehari- } \\
\text { hari. }\end{array}$} \\
\hline 6. Penilaian Autentik & \multicolumn{2}{|c|}{$\begin{array}{l}\text { 1. Unjuk Kerja, dilakukan dengan mengamati anak } \\
\text { didik dalam proses melalukan kebersihan. } \\
\text { 2. Sikap, anak didik diminta menilai diri sendiri, anak } \\
\text { didik diminta menilai temannya, dinilai oleh } \\
\text { gurunya berkaitan dengan membersihkan masjid, } \\
\text { balai desa ataupun lainnya. } \\
\text { 3. Hasil Produk, penilaian terhadap anak didik } \\
\text { berkaiatan dengan proses dan kualitas produknya. }\end{array}$} \\
\hline 7. Unjuk Kerja & \multicolumn{2}{|c|}{$\begin{array}{l}\text { 1. Penilaian terhadap anak didik berkaiatan dengan } \\
\text { proses mengerjakan tugas. }\end{array}$} \\
\hline \multirow{5}{*}{ 8. Sikap } & \multicolumn{2}{|c|}{$\begin{array}{l}\text { PENILAIAN ANTAR ANAK DIDIK BISA JUGA } \\
\text { GURU }\end{array}$} \\
\hline & 4 Selalu & \begin{tabular}{|l}
$\begin{array}{l}\text { Selalu melakukan sesuai dengan } \\
\text { pernyataan. }\end{array}$ \\
\end{tabular} \\
\hline & Sering & $\begin{array}{l}\text { Sering melakukan dan Kadang tidak } \\
\text { melakukan. }\end{array}$ \\
\hline & Kadang & $\begin{array}{l}\begin{array}{l}\text { Kadang melakukan dan Sering tidak } \\
\text { melakukan. }\end{array} \\
\end{array}$ \\
\hline & $\begin{array}{l}\text { Tidak } \\
\text { Pernah }\end{array}$ & \begin{tabular}{|l}
$\begin{array}{l}\text { Tidak pernah melakukan sesuai } \\
\text { pernyataan. }\end{array}$ \\
\end{tabular} \\
\hline
\end{tabular}

\section{Pendampingan Strategi Pembelajaran di Sekolah-sekolah}

Pelaksanaan pendampingan penerapan strategi pembelajaran berbasis multiple intelligences guru SMA di Kecamatan Way Jepara Kabupaten Lampung Timur adalah sebagai berikut: 
PENDAMPINGAN 3

\section{SMA MUH 1}

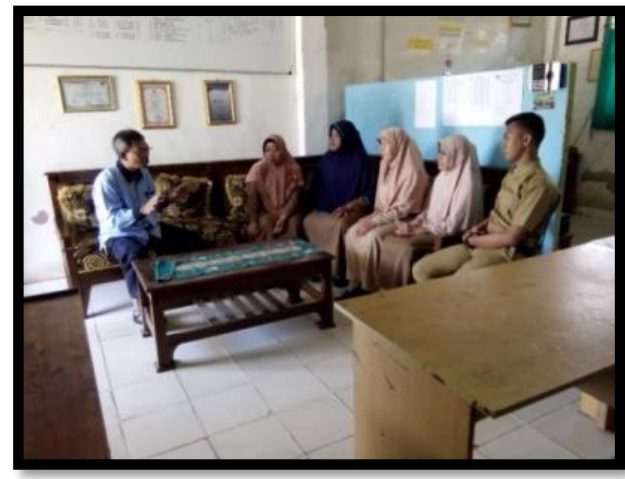

PENDAMPINGAN 4

BERTEMPAT DI SMA SUMBEREJO

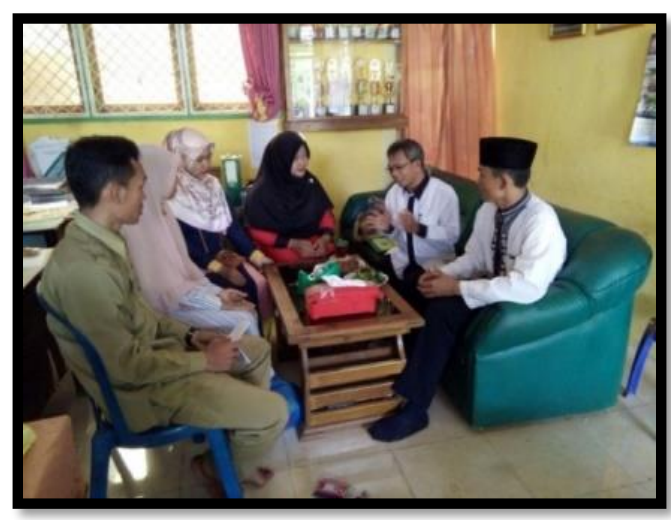

PENDAMPINGAN 5

BERTEMPAT DI SMA MUH 2

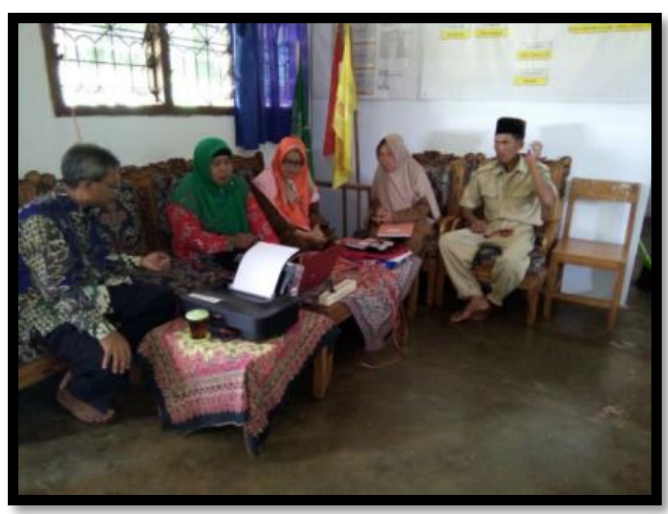




\section{PENDAMPINGAN 6 \\ BERTEMPAT DI STAI DARUSSALAM}

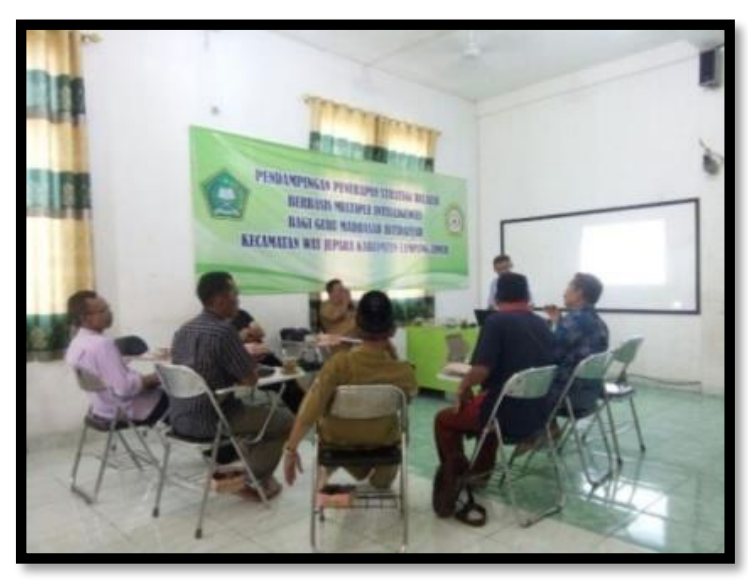

\section{Kesimpulan}

Pendampingan penerapan strategi belajar berbasis Multiple Intelligences bagi Guru SMA kecamatan Way Jepara Kabupaten Lampung Timur berjalan sesuai dengan tahapan-tahapanya. Berdasarkan konsep dan pelaksanaannya pendampingan penerapan strategi belajar berbasis Multiple Intelligences bagi Guru SMA kecamatan Way Jepara Kabupaten Lampung Timur ini memiliki makna yang sangat Signifikensi bagi guru SMA kecamatan Way Jepara Kabupaten Lampung Timur terutama berkenaan dengan pemahaman guru memahami strategi belajar berbasis Multiple Intelligences. Guru mampu menerapkan multi strategi pembelajaran di kelas hingga penilaian autentik. Berdasarkan hasil angket kepada 32 orang guru dari tujuh SMA di kecamatan Way Jepara kabupaten Lampung Timur yang mengikuti pendampingan penerapan strategi belajar berbasis multiple intelligences keberhasilannya mencapai 75\%. Diharapkan adanya pelatihan dan pendampingan secara berkelanjutan kepada guru SMA di Way Jepara Lampung Timur. 


\section{DAFTAR PUSTAKA}

Affandi, Agus dkk. 2013. Modul Participatory Action Reseacrh (PAR). IAIN Sunan Ampel Surabaya: Lembaga Pengabdian Masyarakat (LPM).

Armstrong, T., 2002. Sekolah Para Juara: Menerapkan Multiple Intelegences di Dunia Pendidikan. Bandung: Kaifa

Budiningsih, C. Asri, 2005. Belajar dan Pembelajaran. Jakarta: Rineka Cipta.

Chatib, Munif, Sekolahnya Manusia, 2011, ujung berung, bandung, mizan pustaka.

Danah Zohar \& Ian Marshall: SQ the ultimate intelligence: 2001).

Daniel, Galemon, 1977, Emotional Intellegence, Jakarta, Gramedia Pustaka Utama.

De Porter, Bobbi, 2003, Quantum Teaching, Kaifa, Bandung.

Gardner, H., \& Hatch, T. (1989). Multiple Intelligences go to School: Educational implications of the theory of multiple intelligences. Educational Researcher, 18 (8), 4-9.

Gardner, Howard (1983; 1993) Frames of Mind: The theory of multiple intelligences, New York: Basic Books. The second edition was published in Britain by Fontana Press. $466+$ xxix pages. (All references in this article refer to this second, 10th Anniversary, edition). A major addition to the literature of cognitive psychology being the first full length explication of multiple intelligences.

Gardner, Howard (1999) Intelligence Reframed. Multiple intelligences for the 21st century, New York: Basic Books.

Gardner, Howard (2006) Changing Minds. The art and science of changing our own and other Al-Qur'an Al-Karim, Departemen Agama RI.

LPM IAIN Sunan Ampel Surabaya, Modul Pelatihan Kuliah Kerja Nyata (KKN) Transformatif IAIN Sunan Ampel Surabaya. Surabaya: LPM IAIN Sunan Ampel. 2008

Mansour, Fakih. Jalan Lain. Yogyakarta: Pustaka Pelajar dan Insist Press. 2002. http://www.bantuanhukum.or.id/web/participatory-action-research-par/

Moedjiono dan Dimyati, Moh. 1993. Strategi Belajar Mengajar. Jakarta: Departemen Pendidikan dan Kebudayaan Direktorat Jendral Pendidikan Tinggi. 
people's minds. Boston MA.: Harvard Business School Press.

Rengganis. (2007). Multiple Intelegence (Kecerdasan Majemuk). [Online]. Offset.Tersedia:http:/www.rengganis.blogspot.com [ 20 Oktober 2008]

Suparno, Paul. 2004. Teori Intelegensi Ganda dan Aplikasinya di Sekolah. Yogyakarta: Kanisius

T. Hatch and H. Gardner (1993) 'Finding cognition in the classroom: an expanded view of human intelligence' in G. Salomon (ed.) Distributed Cognitions. Psychological and educational considerations, Cambridge: Cambridge University Press.

Tilaar, H.A.R., 1999, Pendidikan, Kebudayaan Dan Masyarakat Madani Indonesia, PT. Remaja Rosdakarya, Bandung.

Usman, Uzer M. 2006. Menjadi Guru Profsional. Bandung: PT RemajaRosdakarya.

White, J. (1998) Do Howard Gardner's multiple intelligences add up? London: Institute of Education, University of London.

Williams, W. M., Blythe, T., White, N., Li, J., Sternberg, R. J., \& Gardner, H. 1996). Practical intelligence for school. New York: Harper Collins College Publishers. 